\title{
Posttransplant Lymphoproliferative Disorder in Pediatric Patients
}

\author{
Kais Hussein ${ }^{a} \quad$ Christina Tiede $^{b} \quad$ Britta Maecker-Kolhoffc, d Hans Kreipe ${ }^{a}$ \\ anstitute of Pathology, and Departments of brosthetic Dentistry and Biomedical Materials Science and \\ 'Paediatric Haematology and Oncology, and Integrated Research and Treatment Center Transplantation (IFB-Tx), \\ Hannover Medical School, Hannover, Germany
}

\section{Key Words}

Posttransplant lymphoproliferative disorder · Prognostic factors · Solid organ transplantation

\begin{abstract}
Transplantation of solid organs and hematopoietic stem cells is accompanied by profound disturbance of immune function mediated by immunosuppressive drugs or delayed immune reconstitution. Disturbed T cell control of EpsteinBarr virus (EBV)-infected B cells leads to posttransplant lymphoproliferative disorder (PTLD) in up to $10 \%$ of patients. Children are at a higher risk because they are more often EBV-naïve before transplantation. Patients with PTLD often present with unspecific symptoms (pain and organ/graft dysfunction). Depending on the onset of PTLD, manifestations vary between mainly nodal (late PTLD) and extranodal sites (early PTLD). Histology, immunohistology, EBER in situ hybridization and molecular pathology are required for diagnosis and subclassification of PTLD. The three major types are early lesions (resembling reactive proliferations in immunocompetent patients), polymorphic PTLD (proliferation of B and T cells with effacement of histoarchitecture) and monomorphic PTLD (presenting as malignant lymphomas, mainly high-grade B cell lymphomas). In a subfraction of cases, including monomorphic PTLD, reduction of immunosuppressive medication alone is sufficient to induce re-
\end{abstract}

mission. Surgical debulking of tumor mass and anti-CD20antibody treatment with or without chemotherapy (usually at lower dosages than in immunocompetent patients) constitute the basis of additional therapy.

Copyright $\odot 2013$ S. Karger AG, Basel

\section{Introduction}

A relevant transplant complication secondary to immunosuppression is posttransplant lymphoproliferative disorder (PTLD), which is associated with significant morbidity and mortality [1-5]. A considerable subfraction of patients die after PTLD manifestation; 5-year survival rates are $60-70 \%$ [6-8]. The incidence is up to $10 \%$ but varies between 1 and 30\%, which can mainly be explained by the types of transplant organs and immunosuppressive regimes, status of Epstein-Barr virus (EBV) infection prior to transplantation and age at transplantation [1-5]. The transplant organ per se does not determine the risk of developing PTLD. On the one hand the most frequent transplant organ is the kidney, and on the other hand the intensity of immunosuppression differs between organ graft types, with heart, lung and intestinal graft recipients requiring the most intense immunosuppression and thus being at an especially high risk for PTLD development $[1-3,9]$. Furthermore, in general,

\section{KARGER}

E-Mail karger@karger.com

www.karger.com/pat
(C) 2013 S. Karger AG, Basel

$1015-2008 / 13 / 0806-0289 \$ 38.00 / 0$
Kais Hussein, MD

Institute of Pathology, Hannover Medical School

Carl-Neuberg-Strasse 1

DE-30625 Hannover (Germany)

E-Mail hussein.kais@mh-hannover.de 
children are at a higher risk ( $\geq 4$-fold) due to frequent EBV primary infection after transplantation, sometimes related to an organ graft from an EBV-positive donor [13]. Intensity of immunosuppression and age as risk factors are a direct result of the special pathogenesis of PTLD, namely deregulation of $\mathrm{T}$ and $\mathrm{B}$ cell homeostasis.

\section{Pathogenesis and Origin of PTLD}

Under normal conditions, humans are infected with EBV (human herpesvirus 4/HHV-4) during childhood or adolescence and most adults are positive for latent EBV infection [10]. EBV is transmitted via the saliva and infects $\mathrm{B}$ cells by binding to the $\mathrm{B}$ lymphocytic complement component (3d/EBV) receptor 2 (CD21). After EBV integration into the cell, the virus can induce production of its own gene products, including latent membrane proteins (LMP) and Epstein-Barr nuclear antigens (EBNA). Some genetic material of the virus does not encode for proteins, e.g. EBV-encoded small RNA (EBER). EBV proteins interfere with the normal cell homeostasis and lead to the inhibition of apoptosis and the activation of cell cycle [10]. In some nontransplanted cases, clinical presentation of tonsillar EBV infection is infectious mononucleosis (IM). Uncontrolled proliferation of EBVpositive $\mathrm{B}$ cells is usually inhibited by EBV-specific CD4+ and CD8+ T cells and EBV can persist in infected B cells as well as in salivary gland ductal cells [10].

In immunosuppressed patients after transplantation as well as in primary (congenital) or secondary immunodeficiencies (e.g. human immunodeficiency virus; HIV), the number of $\mathrm{T}$ cells is reduced, which may lead to uncontrolled proliferation of EBV-positive B cells [1-3]. In terms of multi-step pathogenesis, accumulation of additional genetic defects transforms EBV-positive B cells to atypical lymphoproliferations. Children have an elevated risk because, in contrast to adults, they are often EBV-naïve before transplantation and acquire EBV infection after transplantation [1-3]. It is important to note that, although all transplanted patients experience immunosuppression, not all develop PTLD. In approximately $30 \%$ of PTLD cases (40-50\% in adults and $10-15 \%$ in children), tumor cells do not express EBV $[1-3,11]$. Other viruses, such as cytomegalovirus (CMV; human herpesvirus 5/HHV-5), have been suggested as pathogenetic drivers of PTLD [1-3]. However, seropositivity for CMV and other viruses are likely to be secondary to immunosuppression, and CMV is not usually detectable in tumor cells. Furthermore, most cases of PTLD are B cell proliferations, while T cell PTLD is rare [1-3]. A subfraction of T cell PTLD cases can be EBV-positive, but the entry mechanism is still unknown because $\mathrm{T}$ cells do not usually express CD21 [1-3]. Therefore, the model of EBV-positive B cells which proliferate without T cell control and results in PTLD can be applied to the majority of cases but not to all, in particular not to EBV-negative PTLD (loss of EBV during evolution?) and T cell PTLD (transient CD21 expression in T cells or alternative entry mechanisms?).

In some cases, specific genetic alterations are acquired by malignant PTLD cells. This is most common in Burkitt's lymphoma characterized by v-myc myelocytomatosis viral oncogene homolog (MYC)/8q24 translocations, but other chromosomal breaks involving chromosomes 1q11-21, 14q32, 16p13 and 11q23-24 have also been described [12]. Furthermore, mutations in genes related to lymphomagenesis most likely contribute to PTLD development, e.g. B cell CLL/lymphoma 2 (BCL2), B cell CLL/lymphoma 6 (BCL6) and paired box 5 (PAX5) [1316]. With more advanced tools to detect genetic alterations such as whole-genome sequencing, our understanding of PTLD development by sequential genetic 'hits' will greatly improve [14].

Except for the transplantation of hematopoietic cells, it is thought that the majority of PTLD cases in solid organ-transplanted patients is derived from the recipient $[1-3]$. Donor-derived PTLD $[16,17]$ is also possible and might be based in some cases on pretransplant genetic alterations. The founder cell is likely a donor lymphocyte in the transplant organ, e.g. portal lymphocytes in the liver [16]. In particular, early-onset manifestation of PTLD $<1$ year after transplantation is not only associated with negative EBV serology at transplantation and EBV-positive $B$ cell PTLD, but also with allograft involvement [1821]. Short tandem-repeat PCR or, if applicable, XY chromosome analysis can easily reveal the origin of the PTLD $[16,17]$. However, the diagnosis of PTLD is established irrespective of the particular origin [22].

\section{Clinical Presentation and Site of Involvement}

The clinical presentation is often unspecific (pain, B symptoms and graft organ or recipient organ dysfunction) and is associated with the site of PTLD manifestation. The main extranodal site is the gastrointestinal tract, but in principle, all localizations are possible, including multifocal tumors [1-3]. PTLD can manifest early or late after transplantation ( $<12$ or $>12$ months), in some cases even after weeks or several years $[18,21]$. Therefore, the differential diagnosis of a PTLD should be considered at any time in patients with transplants. Differences which 
Fig. 1. PTLD subtypes. a Early lesion with follicular lymphatic hyperplasia and some EBV-infected cells. $\times 200$. b Polymorphic PTLD with diffuse effacement of the nodular architecture and EBV-infected cells. $\times 200$. c CD20+ PTLD with diffuse large B cell lymphoma phenotype with plasmoblastic differentiation and some CD30+ anaplastic cells. $\times 100$. d The same monomorphic PTLD (as in c): $>90 \%$ EBER+ cells but only few LPM1 cells. $\times 100$. e Burkitt PTLD with very high proliferation as indicated by Ki67 staining. $\times 200$. f Classic Hodgkin PTLD with CD30+/CD15+/ EBER+ Hodgkin and Reed-Sternberg cells. $\times 100$.
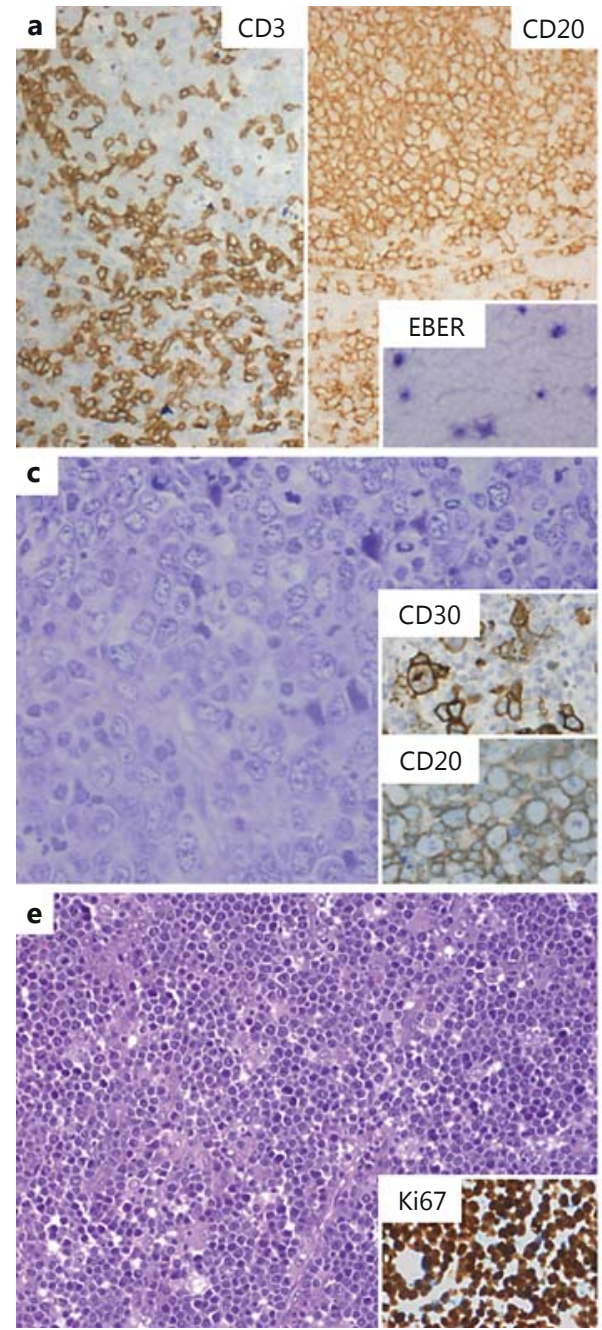
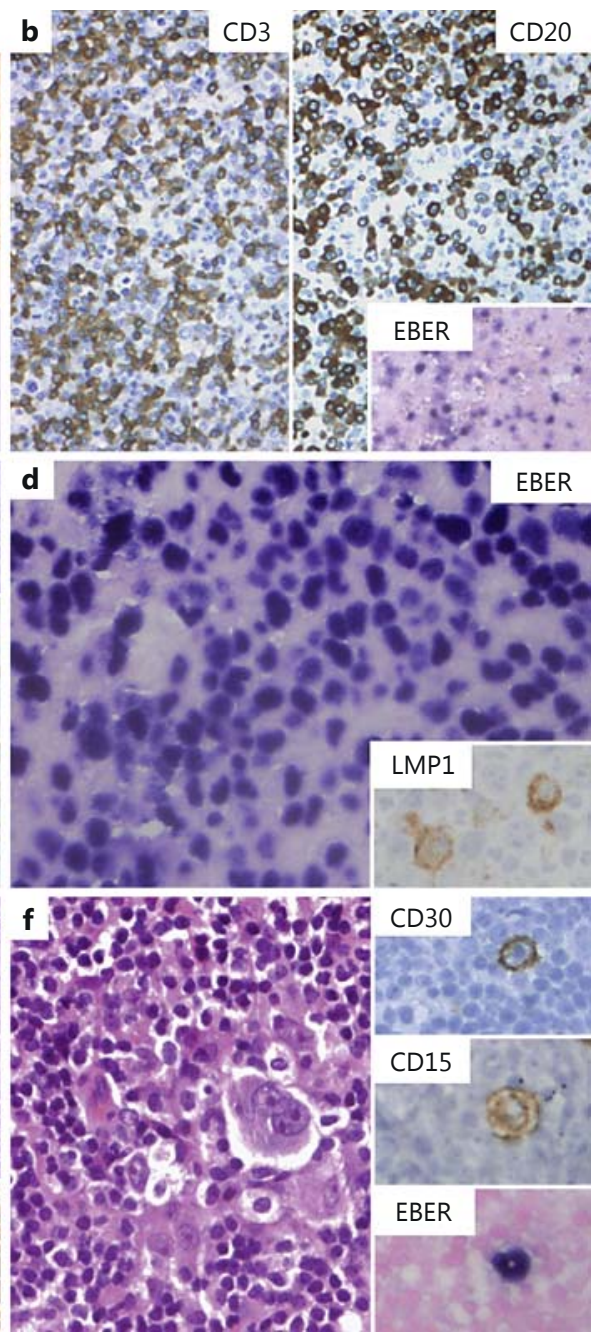

are associated with time of presentation are [18, 21]: (1) site of involvement (early PTLD more often manifests extranodal tumors and in the graft), (2) EBV status (late PTLD is more often negative for EBV) and (3) PTLD subtype (early PTLD more often consists of high-grade B cell proliferations, while late PTLD is more often Burkitt or Hodgkin PTLD). Although suggested by some studies, the overall survival is mainly not affected by the time of presentation [6-8, 23-25].

\section{Diagnosis and Classification of PTLD Subtypes}

Tissue sampling for histology, immunohistochemistry and EBER in situ hybridization is mandatory for diagnosis $[3,4,22,26]$. Frozen or formalin-fixed and paraffinembedded tissues can be used for PCR analysis of clonality and/or fluorescence in situ hybridization, in particular for the evaluation of rearrangements of $8 \mathrm{q} 24$, the gene locus of MYC. Serological markers, such as increasing EBV load $[26,27]$ or chemokine (C-X-C motif) ligand 13 (CXCL13) [28] and positron emission tomography with [18F]-2-fluoro-2-desoxy-glucose [29] may facilitate discrimination between PTLD and other posttransplant complications, but these methods have a much lower specificity and sensitivity than histology and are therefore not applicable for primary diagnostics. Furthermore, serological markers are mainly analyzed in extracranial PTLD, although cerebral manifestation can be associated with no detectable EBV in the peripheral blood but EBV positivity in the liquor [30,31].

PTLD diagnostics have several similarities but also some differences when compared to the diagnostics of reactive changes and conventional lymphomas. Three major types with several subtypes must be discriminated (fig. 1, 2). If present, the quantity of EBV-positive cells 
Fig. 2. WHO 2008 classification of PTLD. NHL-B = B cell non-Hodgkin lymphoma; $\mathrm{CHL}=$ classic Hodgkin lymphoma-type PTLD; IM-like = IM-like early lesion; NHL-T $=$ T cell non-Hodgkin lymphoma.

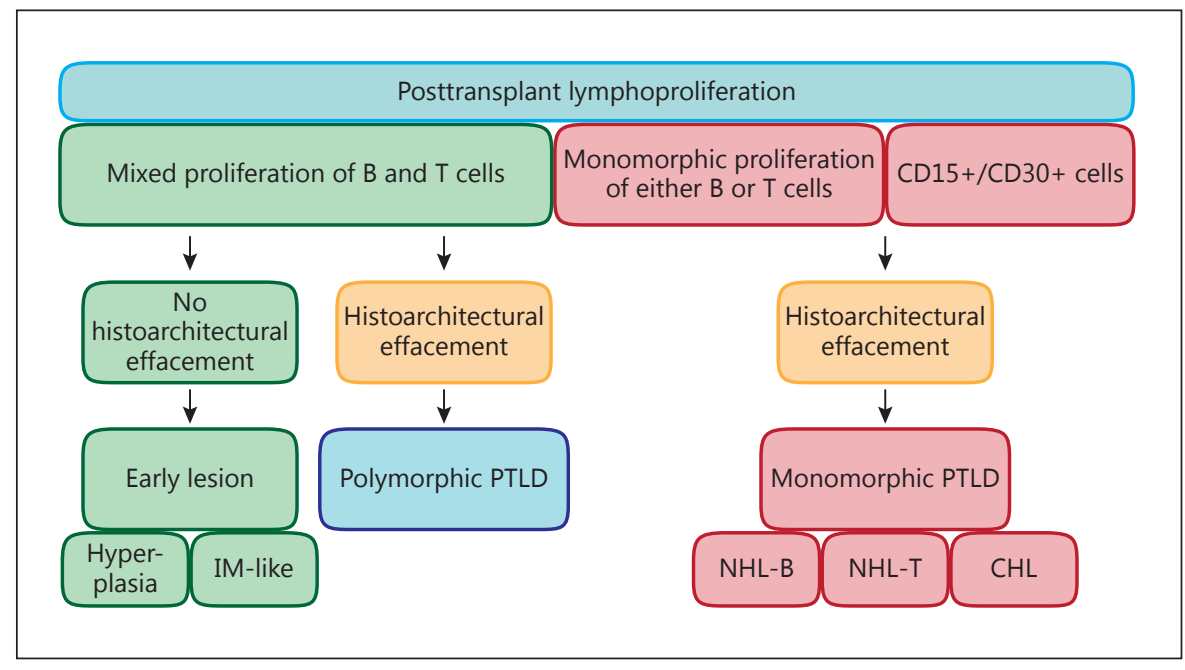

alone is not specific for discriminating PTLD subtypes. Detection of monoclonal B, plasma or T cells by PCR speaks in favor of a lymphoma-like proliferation, but molecular pathology must always be correlated with morphology [3, 22]. In particular, the following pitfalls should be taken into account: (1) technical pseudo-clonality due to a small amount of analysed cells (e.g. biopsy specimen), (2) technical pseudo-polyclonality due to hypermutation of the corresponding immunoglobulin heavy chain $(\mathrm{IgH})$ or $\mathrm{T}$ cell receptor gene segments (PCR primers can no longer bind to the altered DNA sequence but detect the polyclonal background) and (3) transient dominant proliferation of one clone or oligoclonality [32].

\section{Early Lesions}

This mostly benign type is indistinguishable from reactive changes in immunocompetent individuals [22]. In fact, by definition, every lymphatic hyperplasia in transplanted patients is an early lesion [22], but only early lesions with formation of a tumor mass (e.g. lymphadenopathy or swelling of tonsils) are clinically relevant. Due to its reactive appearance, an early lesion is usually not perceived as a 'true' PTLD in the narrower sense. The term 'early' does not refer to the time of manifestation after transplantation and early lesions can occur $>12$ months after transplantation. Furthermore, 'early' does not imply adenoma-carcinoma-like sequential evolution; development from early lesion to high-grade PTLD cannot be excluded but is not a necessity.
Two subtypes can be distinguished [22]: (1) plasma cell-rich lymphatic hyperplasia with normal histoarchitecture of the lymphatic tissue, e.g. tonsils, lymph nodes or mucosa-associated lymphatic tissues, and (2) an IMlike early lesion, equivalent to IM in immunocompetent patients, which shows subepithelial EBV-positive blasts and ulcerations of the tonsil surface.

\section{Polymorphic PTLD}

This type is characterized by mixed proliferation of $\mathrm{B} /$ plasma and $\mathrm{T}$ cells, but in contrast to early lesions, the histoarchitecture is disturbed [22]. Diffuse effacement of follicular organization is a typical feature. Furthermore, the criteria for the diagnosis of any other lymphoma must not be met. In particular, lymphomas with 'hidden' neoplastic blasts should be carefully excluded, e.g. T cell-rich diffuse large B cell lymphoma (DLBCL) and Hodgkin lymphoma (HL).

\section{Monomorphic PTLD}

Almost all lymphomas which are diagnosed in transplanted patients are, by definition, monomorphic PTLD [22]. The only exceptions are low-grade/indolent B cell lymphomas which are considered to be incidental and, anyhow, are rare in transplant patients, in particular in children [22]. The most frequent subtype is B cell PTLD, in particular DLBCL, which often shows a plasmablastic differentiation [3]. Burkitt PTLD is less frequent than 
Table 1. EBV latency types in different subtypes of PTLD

\begin{tabular}{|c|c|c|c|c|}
\hline & Type 0 & Type I & Type II & Type III \\
\hline EBER & + & + & + & + \\
\hline EBNA-2/EBNA-3 & - & - & - & + \\
\hline LMP1 & - & - & + & + \\
\hline LMP2 & + & - & + & + \\
\hline$\overline{\text { PTLD }}$ & & Burkitt PTLD & $\begin{array}{l}\text { Hodgkin PTLD, T cell PTLD, } \\
\text { polymorphic PTLD }\end{array}$ & $\begin{array}{l}\text { IM-like early lesion, DLBCL } \\
\text { PTLD, polymorphic PTLD }\end{array}$ \\
\hline
\end{tabular}

DLBCL and shows an 8q24 translocation. In cases with high proliferation (>95\%) but no detection of MYC rearrangement, a Burkitt-like high-grade B cell PTLD should be considered.

CD3 + $\mathrm{T}$ cell PTLD comprises $<10 \%$ of all cases of monomorphic PTLD $[22,33]$. In contrast to B cell PTLD, which usually manifests as DLBCL or Burkitt's lymphoma subtypes, T cell PTLD shows a variety of T cell lymphoma subtypes from relatively benign large granular lymphocytic leukemia (LGL) types to high-grade T cell lymphomas [33].

In the WHO classification, CD30+/CD15+ HL PTLD is considered to be a separate group, the 'classical' HL type, and does not belong to monomorphic PTLD [22]. However, in daily practice, 'monomorphic PTLD' is the designation for all lymphoma phenotypes, including HL PTLD. Furthermore, Hodgkin-like PTLD with CD20+/ CD30+/CD15- blasts is considered more likely to be DLBCL-like monomorphic PTLD (in particular T cellrich DLBCL) but not 'true' classic HL PTLD [22]. Polymorphic PTLD with some activated CD30+ B cell blasts is another differential diagnosis. The discrimination can be difficult in individual cases [34].

Manifestation of concurrent or sequential B and T cell PTLD is rare but has been described in some patients [35].

\section{EBV Latency Types in PTLD}

EBER+ cases can be further evaluated for EBV latency (table 1) [10]. In particular, evaluation of latency types can supplement the differential diagnostic approach for the discrimination of HL from HL-like PTLD (latency type II vs. type III) [36].
Immunohistochemistry of tumor cells should include at least two EBV proteins: LMP1 and EBNA-2 or EBNA3 (EBNA-2 and EBNA-3 are usually coexpressed) [10]. EBNA-1 is coexpressed with EBER and therefore does not discriminate between latency types. EBER+ PTLD shows the following characteristic latency types which correspond to latency types in sporadic lymphomas (table 1) [10, 36, 37]: Burkitt PTLD can be EBNA-2-/LMP1- (latency type I), CD30+/CD15+ HL PTLD is EBNA-2-/ LMP1+ (latency type II) and IM-like early lesion, DLBCL as well as CD30+/CD15- HL-like PTLD is EBNA-2+/ LMP1+ (latency type III). Polymorphic PTLD can be EBNA-2-/LMP1+ or EBNA-2+/LMP1+ (latency type II or III) [37].

\section{Prognosis and Therapy}

Several studies have focused on the elucidation of prognostic factors for patients with PTLD. Advanced disease dissemination has been associated with poor prognosis, which is attributed in some studies to special-site involvement like bone marrow, the central nervous system and the transplant organ $[6-8,33]$. Other factors determining prognosis are an elevated lactate dehydrogenase, poor performance status at diagnosis and, in some studies, EBV-negative lymphoma [38]. In prospective studies, children have a more favorable prognosis than adults. Two-year overall survival is around $85 \%$ in children with $70 \%$ surviving disease-free [39], while in the adult PTLD population $60 \%$ are alive after 2 years with approximately $50 \%$ remaining disease-free [40]. This difference in survival time may in part be due to more favorable PTLD subtypes (more EBV-positive PTLD) in children as well as a greater tolerance of treatment-related morbidity. 
The major therapy for all cases of PTLD, including high-grade lymphoma subtypes, is the reduction of immunosuppressive medication. This alone can lead to complete remission in a subfraction of cases. Surgery for tumor resection or debulking depends on the localization of the mass, e.g. a tonsillectomy in an IM-like lesion.

Patients with polymorphic and monomorphic PTLD can be treated with monoclonal anti-CD20 antibodies (rituximab), and chemotherapy can also be applied [1-3, $5-8,38]$. Therapy of PTLD tumors which have manifested in the central nervous system is mainly similar to therapy of PTLD at other sites, but can be supplemented by methotrexate [38]. In addition, we could show that in pediatric cerebral PTLD which does not respond to the conventional administration of rituximab (presumably due to insufficient penetration of the drug to the site of the lesion), intrathecal administration can be successfully applied [39].

Current pediatric treatment protocols for CD20-positive PTLD are based on rituximab with or without reduced intensity chemotherapy regimens [40]. In contrast, the most recent adult studies used rituximab in combination with standard-dose CHOP-based regimens [41]. Whether the rate of patients with durable remissions after rituximab monotherapy differs between children and adults is currently under investigation.

In addition to reduced immunosuppression, pediatric classic HL PTLD is treated similarly to HL in nontransplanted patients [42].

In T cell PTLD, favorable prognostic factors are LGL PTLD, young age, a combination of radiotherapy/radiochemotherapy and reduced immunosuppression, while the hepatosplenic $\mathrm{T}$ cell lymphoma subtype and cases with involvement of bone marrow, central nervous system or graft have an adverse prognosis [33].

Effective protocols for prophylactic or therapeutic antiviral therapies (e.g. ganciclovir) are still under investigation [38].

EBV-targeting T cells are still not routinely used but this potentially nontoxic treatment is a promising addition to the current therapeutic options [43].

\section{Potential Complications}

Complications in the course of treatment of PTLD are sometimes difficult to handle. The individual's organ graft function and comorbidities should always be considered. Reduction of immunosuppression may lead to graft rejection and careful titration of immunosuppression is required in these cases.
Only partial remission, relapse and/or progress of the disease under chemotherapy are major problems. Some patients can have remission of the initial PTLD, but a later manifestation of the same histological PTLD subtype, in particular DLBCL. In these cases, discrimination between relapse of the first PTLD and manifestation of an unrelated second PTLD can be difficult. According to our experience in pediatric PTLD, molecular analysis of clonal relation (e.g. IgH) can clarify this issue, at least in a subfraction of cases.

Special caution should be taken in children with intestinal PTLD manifestation [44]. In particular, patients with diffuse lymphocytic infiltration of the gut wall may experience bowel perforation, often with a fatal outcome, after immunotherapy with rituximab. It might be possible that, in these cases, rapid clearance and/or necrosis of $B$ cells can lead to destabilization of the gut wall. Longer intervals between therapies might prevent such complications because inflammatory reaction would allow formation of scar tissue in the wall. Our knowledge of the exact pathophysiology is sparse but patients with intestinal involvement should be monitored more carefully for signs of gut perforation.

\section{Conclusion}

Children have an increased risk for developing PTLD after organ transplantation because they are more often EBV-naïve than adults before transplantation.

Diagnosis requires a morphological and molecular evaluation of tumor specimens. The three main types are early lesions (plasma cell-rich hyperplasia and IM-like lesion), polymorphic PTLD (mixed B and T cell proliferation with effacement of follicular histoarchitecture) and monomorphic, lymphoma-like PTLD.

Most cases of pediatric PTLD are EBV-associated and most cases of monomorphic PTLD are high-grade B cell proliferations.

Therapy is based on reduced immunosuppression, anti-CD20-antibody treatment and low-dose chemotherapy. Reduced immunosuppression alone can lead to complete remission in a subfraction of cases, even in high-grade B cell PTLD.

\section{Acknowledgements}

B.M.-K. received financial support from the German Children's Cancer Fund and IFB-Tx. 


\section{References}

1 Everly MJ, Bloom RD, Tsai DE, Trofe J: Posttransplant lymphoproliferative disorder. Ann Pharmacother 2007;41:1850-1858.

-2 Shroff R, Rees L: The post-transplant lymphoprolipherative disorder - a literature review. Pediatr Nephrol 2004;19:369-377.

-3 Hussein K, Maecker-Kolhoff B, Klein C, Kreipe H: Transplant-associated lymphoproliferation. Pathologe 2011;32:152-158.

4 Parker A, Bowles K, Bradley JA, Emery V, Featherstone C, Gupte G, Marcus R, Parameshwar J, Ramsay A, Newstead C, Haemato-Oncology Task Force of the British Committee for Standards in Haematology and British Transplantation Society: Diagnosis of post-transplant lymphoproliferative disorder in solid organ transplant recipients - BCSH and BTS Guidelines. Br J Haematol 2010;149:675-692.

5 Parker A, Bowles K, Bradley JA, Emery V, Featherstone C, Gupte G, Marcus R, Parameshwar J, Ramsay A, Newstead C, Haemato-Oncology Task Force of the British Committee for Standards in Haematology and British Transplantation Society: Management of post-transplant lymphoproliferative disorder in adult solid organ transplant recipients - BCSH and BTS Guidelines. Br J Haematol 2010;149:693-705.

-6 Evens AM, David KA, Helenowski I, Nelson B, Kaufman D, Kircher SM, Gimelfarb A, Hattersley E, Mauro LA, Jovanovic B, Chadburn A, Stiff P, Winter JN, Mehta J, Van Besien K, Gregory S, Gordon LI, Shammo JM, Smith SE, Smith SM: Multicenter analysis of 80 solid organ transplantation recipients with posttransplantation lymphoproliferative disease: outcomes and prognostic factors in the modern era. J Clin Oncol 2010;28:1038-1046.

77 Webber SA, Naftel DC, Fricker FJ, Olesnevich P, Blume ED, Addonizio L, Kirklin JK, Canter CE, Pediatric Heart Transplant Study: Lymphoproliferative disorders after paediatric heart transplantation: a multi-institutional study. Lancet 2006;367:233-239.

-8 Maecker B, Jack T, Zimmermann M, AbdulKhaliq H, Burdelski M, Fuchs A, Hoyer P, Koepf S, Kraemer U, Laube GF, MüllerWiefel DE, Netz H, Pohl M, Toenshoff B, Wagner HJ, Wallot M, Welte K, Melter M, Offner G, Klein C: CNS or bone marrow involvement as risk factors for poor survival in post-transplantation lymphoproliferative disorders in children after solid organ transplantation. J Clin Oncol 2007;25:4902-4908.

9 Mucha K, Foroncewicz B, Ziarkiewicz-Wróblewska B, Krawczyk M, Lerut J, Paczek L: Post-transplant lymphoproliferative disorder in view of the new WHO classification: a more rational approach to a protean disease? Nephrol Dial Transplant 2010:25:2089-2098.
10 Luzuriaga K, Sullivan JL: Infectious mononucleosis. N Engl J Med 2010;362:1993-2000.

$>11$ Leblond V, Davi F, Charlotte F, Dorent R, Bitker MO, Sutton L, Gandjbakhch I, Binet JL, Raphael M: Posttransplant lymphoproliferative disorders not associated with EpsteinBarr virus: a distinct entity? J Clin Oncol 1998; 16:2052-2059.

12 Vakiani E, Nandula SV, Subramaniyam S, Keller CE, Alobeid B, Murty VV, Bhagat G: Cytogenetic analysis of B-cell posttransplant lymphoproliferations validates the World Health Organization classification and suggests inclusion of florid follicular hyperplasia as a precursor lesion. Hum Pathol 2007;38: 315-325.

13 Vakiani E, Basso K, Klein U, Mansukhani MM, Narayan G, Smith PM, Murty VV, Dalla-Favera R, Pasqualucci L, Bhagat G: Genetic and phenotypic analysis of B-cell post-transplant lymphoproliferative disorders provides insights into disease biology. Hematol Oncol 2008;26:199-211.

14 Rinaldi A, Kwee I, Poretti G, Mensah A, Pruneri G, Capello D, Rossi D, Zucca E, Ponzoni M, Catapano C, Tibiletti MG, Paulli M, Gaidano G, Bertoni F: Comparative genomewide profiling of post-transplant lymphoproliferative disorders and diffuse large B-cell lymphomas. Br J Haematol 2006;134:27-36.

15 Rinaldi A, Capello D, Scandurra M, Greiner TC, Chan WC, Bhagat G, Rossi D, Morra E, Paulli M, Rambaldi A, Rancoita PM, Inghirami G, Ponzoni M, Moreno SM, Piris MA, Mian M, Chigrinova E, Zucca E, Favera RD, Gaidano G, Kwee I, Bertoni F: Single nucleotide polymorphism-arrays provide new insights in the pathogenesis of post-transplant diffuse large B-cell lymphoma. Br J Haematol 2010;149:569-577.

16 Capello D, Rasi S, Oreste P, Veronese S, Cerri M, Ravelli E, Rossi D, Minola E, Colosimo A, Gambacorta M, Muti G, Morra E, Gaidano G: Molecular characterization of post-transplant lymphoproliferative disorders of donor origin occurring in liver transplant recipients. J Pathol 2009;218:478-486.

17 Bredt M, Schönfeld G, Kleeberger W, König E, Kröning H, Kettner E, Al-Ali HK, Niederwieser D, Kreipe H: Late-onset Epstein-Barr virus (EBV)-negative extranodal B-precursor lymphoblastic lymphoma of donor origin after hematopoietic stem cell transplantation (HSCT). Bone Marrow Transplant 2003;31: 1071-1072.

18 Ghobrial IM, Habermann TM, Macon WR, Ristow KM, Larson TS, Walker RC, Ansell SM, Gores GJ, Stegall MD, McGregor CG: Differences between early and late posttransplant lymphoproliferative disorders in solid organ transplant patients: are they two different diseases? Transplantation 2005;79:244247.
19 Paranjothi S, Yusen RD, Kraus MD, Lynch JP, Patterson GA, Trulock EP: Lymphoproliferative disease after lung transplantation: comparison of presentation and outcome of early and late cases. J Heart Lung Transplant 2001; 20:1054-1063.

20 Quinlan SC, Pfeiffer RM, Morton LM, Engels EA: Risk factors for early-onset and late-onset post-transplant lymphoproliferative disorder in kidney recipients in the United States. Am J Hematol 2011;86:206-209.

21 Schober T, Framke T, Kreipe H, Schulz TF, Grohennig A, Hussein K, Baumann U, Pape L, Schubert S, Wingen AM, Jack T, Koch A, Klein C, Maecker-Kolhoff B: Characteristics of early and late PTLD development in pediatric solid organ transplant recipients. Transplantation 2013;95:240-246.

22 Swerdlow SH, Webber SA, Chadburn A, Ferry JA: Post-transplant lymphoproliferative disorder; in Swerdlow SH, Campo E, Harris $\mathrm{NL}$, et al (eds): WHO Classification of Tumours of Haematopoietic and Lymphoid Tissues, ed 4. Lyon, IRAC, 2008, pp 343-351.

23 Caillard S, Lelong C, Pessione F, Moulin B: Post-transplant lymphoproliferative disorders occurring after renal transplantation in adults: report of 230 cases from the French Registry. Am J Transplant 2006;6:2735-2742.

24 Trofe J, Buell JF, Beebe TM, Hanaway MJ, First MR, Alloway RR, Gross TG, Succop P, Woodle ES: Analysis of factors that influence survival with post-transplant lymphoproliferative disorder in renal transplant recipients: the Israel Penn International Transplant Tumor Registry experience. Am J Transplant 2005;5:775-780.

25 Metzelder ML, Schober T, Grigull L, Klein C, Kuebler JF, Ure BM, Maecker-Kolhoff B: The role of laparoscopic techniques in children with suspected post-transplantation lymphoproliferative disorders. J Laparoendosc Adv Surg Tech A 2011;21:767-770.

26 Imadome KI, Fukuda A, Kawano F, Imai Y, Ichikawa S, Mochizuki M, Shigeta T, Kakiuchi T, Sakamoto S, Kasahara M, Fujiwara S: Effective control of Epstein-Barr virus infection following pediatric liver transplantation by monitoring of viral DNA load and lymphocyte surface markers. Pediatr Transplant 2012;16:748-757.

27 Ruf S, Behnke-Hall K, Gruhn B, Bauer J, Horn M, Beck J, Reiter A, Wagner HJ: Comparison of six different specimen types for EpsteinBarr viral load quantification in peripheral blood of pediatric patients after heart transplantation or after allogeneic hematopoietic stem cell transplantation. J Clin Virol 2012; 53:186-194. 
-28 Schiffer L, Henke-Gendo C, Wilsdorf N, Hussein K, Pape L, Schmitt C, Haller H, Schiffer M, Klein C, Kreipe H, Maecker-Kolhoff B: CXCL13 as a novel marker for diagnosis and disease monitoring in pediatric PTLD. Am J Transplant 2012;12:1610-1607.

-29 von Falck C, Maecker B, Schirg E, Boerner AR, Knapp WH, Klein C, Galanski M: Posttransplant lymphoproliferative disease in pediatric solid organ transplant patients: a possible role for [18F]-FDG-PET(/CT) in initial staging and therapy monitoring. Eur J Radiol 2007;63:427-435.

- 30 Boersma MN, van der Zanden A, Laverman GD, Sanders JS, de Vries PA: Epstein-Barr virus-positive post-transplant lymphoproliferative disorder of the central nervous system, after renal transplantation with a discrepancy in viral load between peripheral blood and cerebrospinal fluid. Transpl Int 2012;25:e113116.

- 31 Shimizu H, Saitoh T, Koya H, Yuzuriha A, Hoshino T, Hatsumi N, Takada S, Nagaki T, Nojima Y, Sakura T: Discrepancy in EBVDNA load between peripheral blood and cerebrospinal fluid in a patient with isolated CNS post-transplant lymphoproliferative disorder. Int J Hematol 2011;94:495-498.

- 32 van Krieken JH, Langerak AW, Macintyre EA, Kneba M, Hodges E, Sanz RG, Morgan GJ, Parreira A, Molina TJ, Cabeçadas J, Gaulard P, Jasani B, Garcia JF, Ott M, Hannsmann ML, Berger F, Hummel M, Davi F, Brüggemann M, Lavender FL, Schuuring E, Evans PA, White H, Salles G, Groenen PJ, Gameiro P, Pott Ch, Dongen JJ: Improved reliability of lymphoma diagnostics via PCR-based clonality testing: report of the BIOMED-2 Concerted Action BHM4CT98-3936. Leukemia 2007;21:201-206.
33 Tiede C, Maecker-Kolhoff B, Klein C, Kreipe $\mathrm{H}$, Hussein K: Risk factors and prognosis in T-cell post-transplant lymphoproliferative diseases - re-evaluation of 163 cases. Transplantation 2013;95:479-488.

34 Ziarkiewicz-Wróblewska B, Górnicka B, Gierej B, Suleiman W, Nowacka-Cieciura E, Durlik M, Bogdańska M, Wasiutyński A, Pileri SA: Hodgkin-like lymphoma, simulating anaplastic large cell lymphoma in the patient after renal transplantation - unusual case report and literature review. Pol J Pathol 2008; 59:63-69.

Morovic A, Jaffe ES, Raffeld M, Schrager JA: Metachronous EBV-associated B-cell and Tcell posttransplant lymphoproliferative disorders in a heart transplant recipient. Am J Surg Pathol 2009;33:149-154.

-36 Rohr JC, Wagner HJ, Lauten M, Wacker HH, Jüttner E, Hanke C, Pohl M, Niemeyer CM: Differentiation of EBV-induced post-transplant Hodgkin lymphoma from Hodgkin-like post-transplant lymphoproliferative disease. Pediatr Transplant 2008;12:426-431.

- 37 Shaknovich R, Basso K, Bhagat G, Mansukhani M, Hatzivassiliou G, Murty VV, Buettner M, Niedobitek G, Alobeid B, Cattoretti G: Identification of rare Epstein-Barr virus infected memory $B$ cells and plasma cells in non-monomorphic post-transplant lymphoproliferative disorders and the signature of viral signaling. Haematologica 2006;91: 1313-1320.

-38 Jagadeesh D, Woda BA, Draper J, Evens AM: Post transplant lymphoproliferative disorders: risk, classification, and therapeutic recommendations. Curr Treat Options Oncol 2012;13:122-136.
39 van de Glind G, de Graaf S, Klein C, Cornelissen M, Maecker B, Loeffen J: Intrathecal rituximab treatment for pediatric post-transplant lymphoproliferative disorder of the central nervous system. Pediatr Blood Cancer 2008;50:886-888.

40 Gross TG, Orjuela MA, Perkins SL, Park JR, Lynch JC, Cairo MS, Smith LM, Hayashi RJ: Low-dose chemotherapy and rituximab for posttransplant lymphoproliferative disease (PTLD): a Children's Oncology Group report. Am J Transplant 2012;12:3069-3075.

41 Trappe R, Oertel S, Leblond V, Mollee P, Sender M, Reinke P, Neuhaus R, Lehmkuhl H, Horst HA, Salles G, Morschhauser F, Jaccard A, Lamy T, Leithäuser M, Zimmermann $\mathrm{H}$, Anagnostopoulos I, Raphael M, Riess H, Choquet S, German PTLD Study Group, European PTLD Network: Sequential treatment with rituximab followed by $\mathrm{CHOP}$ chemotherapy in adult B-cell post-transplant lymphoproliferative disorder (PTLD): the prospective international multicentre phase 2 PTLD-1 trial. Lancet Oncol 2012;13:196-206.

42 Dharnidharka VR, Douglas VK, Hunger SP, Fennell RS: Hodgkin's lymphoma after posttransplant lymphoproliferative disease in a renal transplant recipient. Pediatr Transplant 2004;8:87-90.

43 Bollard CM, Rooney CM, Heslop HE: T-cell therapy in the treatment of post-transplant lymphoproliferative disease. Nat Rev Clin Oncol 2012;9:510-519.

44 Tai CC, Curtis JL, Szmuszkovicz JR, Horn MV, Ford HR, Woo MS, Wang KS: Abdominal involvement in pediatric heart and lung transplant recipients with posttransplant lymphoproliferative disease increases the risk of mortality. J Pediatr Surg 2008;43:21742177. 